\title{
Internet Banking Adoption in Saudi Arabia: An Empirical Study
}

\author{
Shahzada Nayyar Jehan ${ }^{1} \&$ Zaid Ahmad Ansari ${ }^{2}$ \\ ${ }^{1}$ Professor, Tohoku University of Community Service and Science, Sakata, Japan \\ ${ }^{2}$ Associate Professor, College of Business and Economics, Qassim University, Saudi Arabia \\ Correspondence: Zaid Ahmad Ansari, College of Business and Economics, Qassim University, Saudi Arabia.
}

Received: July 12, 2018 Accepted: August 8, 2018 Online Published: August 21, 2018

doi:10.5539/ijms.v10n3p57 URL: https://doi.org/10.5539/ijms.v10n3p57

\begin{abstract}
The current study was conducted with the primary objective to explore the factors and analyse their relevance and importance in the adoption of internet banking in Saudi Arabia. In this paper, we gathered evidence from 300 consumers about the factors they considered important before opting for internet banking. Responses were collected by administering a Likert scale close ended structured questionnaire. Factor analysis was conducted to group the factors into significant components areas. The results showed that the factors under study explained $91.508 \%$ of the variance in internet banking adoption. Also, that the trust is the most crucial factor for the consumers of internet banking ( $25.950 \%$ variance) followed by ease of using internet banking services $(25.188 \%$ variance); whereas $21.921 \%$ variance explained efficiency and effectiveness of the internet banking and $18.449 \%$ variance explained the importance of information about the internet banking to the consumers. The findings of this study will allow the banks to develop internet banking strategies tailored to the expectations of their clients. The study recommends banks to focus on building the trust of the customers and should also make internet banking as convenient as possible. Besides, the internet banking should be efficient and effective in delivering banking services. Furthermore, there should be sufficient information available regarding internet banking. Saudi Arabia is the largest economy in the Middle East. Of late the country has focused on the modernisation of its economy and has been trying in earnest to integrate with the world economy. The e-commerce activities are also growing; however, research in internet banking is limited. The findings of the paper can serve as a model for the adoption of internet banking especially in Saudi Arabia and in the Middle East or elsewhere in general. The research was conducted in Saudi Arabia, and more researches could be conducted based on this study in other parts of the Middle East for more generalisation of the findings.
\end{abstract}

Keywords: banking consumer, internet banking, Saudi Arabia, trust

\section{Introduction}

Internet banking refers to the use of a bank's website through which customers access their banking accounts, conduct financial transactions, and obtain general information on bank products and services. It is a form of "virtual channel" that allows customers to interact with a bank conveniently by providing them with an opportunity to acquire banking services anytime and anywhere (Casalo et al., 2007). The developments in information technology have hugely influenced the development of more flexible payment methods and more user-friendly banking services (Akinci et al., 2004). The rapid diffusion of the internet also radically changed the delivery channels used by the financial services industry. The potential of online or internet banking is well recognized (Booz, Allen, \& Hamilton, 1997). Many financial institutions use internet banking as a distribution channel for the bank's services because the internet facilitates remote access to banks (Riffai et al., 2012). Internet influences the banking industry and provides new opportunities to banks in developing their services (Chechen et al., 2016). Internet banking as a service delivery channel has acquired popularity due to the low cost per transaction and a wide variety of access options for the customer base (Shah \& Siddiqui, 2006). The banking industry adopted e-banking as a tool of e-commerce with improved services and operations of banks (Chong et al., 2010), saving costs (Pikkarainen et al., 2004) and facilitating the business activities of bank customers through provision of "anytime and anywhere service" (George \& Kumar, 2013).

Introduced in 1997 (Furst et al., 2002), internet banking is a process innovation which allows existing banks to centralise back-office operations and increase their efficiency; also the existence of virtual and branch offices has enhanced interaction between customers and the bank (Arnaboldi \& Clayes, 2010). The efficient delivery of 
banking services encourages banks to accelerate adoption process, knowing that the cost of delivering a service over the internet is much less than delivering the same service over the counter (Polatogu \& Ekin, 2001). The internet makes it easier for buyers and sellers to compare prices, reduces the number of intermediaries, cuts transaction costs, improves the functioning of the price mechanism, and thereby increases competition (Lal \& Savary, 1999; Markillie, 2004; Zettlemeyer et al., 2006).

Internet banking gives a competitive advantage to the banks by enhancing the quality of customer services and reducing operational costs (Jourdan \& Katz, 1999). Internet banking provides many benefits not only for banks but also for customers as they can conduct financial activities from anywhere at any time. Ease of transaction and avoidance of queues and restrictive branch operating hours and cheaper costs make internet banking popular with consumers. At the same time, banks could provide lower cost financial services, and enhance customer satisfaction (Keswani \& Chaturvedi, 2010). Internet banking gives banks a competitive advantage by enhancing the quality of customer services and reducing their operational costs (Jourdan \& Katz, 1999). The advantages of internet banking cannot be accomplished unless customers accept the internet banking services (Chiou \& Shen, 2012). Compared to physical banking, internet banking has some unique characteristics, such as the extensive use of technologies and the impersonal nature of the online environment. These characteristics, however, give rise to customers' uncertainty about using internet banking for financial transactions (Gan et al., 2006; Yousafzai et al., 2003). In fact, there are still a large group of customers who are reluctant to adopt internet banking due to this uncertainty (Kuisma et al., 2007; Littler \& Melanthiou, 2006). As a result, banks and policymakers consider increasing the adoption rate of internet banking as their priority when creating strategic plans to build competitive advantage (Shih \& Fang, 2004).

\section{Literature Review}

Various factors can influence internet adoption by banking consumers. Many studies have been conducted with the objective of understanding the factors affecting the adoption of internet banking by users in developed countries (Daniel, 1999; Sathye, 1999; Ramsey \& Smith, 1999). According to the findings of Fawzy and Esawai (2017), factors important for the adoption of internet banking in Egypt were perceived usefulness and ease of use. Also, the findings also showed that perceived privacy and security has a positive effect on customers' attitude toward internet banking. Besides these, their findings also showed that computer efficacy had a positive impact on customers' attitude and intention which in turn influences the adoption of internet banking. They also found that the perceived risk has a negative effect on the consumer's intentions towards the adoption of internet banking.Lack of trust has been identified as one of the major obstacles to the spread of internet banking (Rexha et al., 2003). Several studies have found that customers cite a number of reasons for preferring e-banking like transaction speed, lower management costs, greater control over service delivery, shorter wait time, a perception of more customized service and convenient access to services that is not limited by time or space (Lee, 2009; Montazemi \& Qahri-Saremi, 2015, Ayo et al., 2016; Hui Ling et al., 2015; Lee, 2009; Tan \& Teo, 2000; Yousafzai et al., 2003). According to Ba (2001), the reputation of internet banking is one of the principal factors influencing the use of this new channel of communication. Suh and Han (2002) demonstrated that the perceived usefulness of consumers of internet banking significantly influences trust in these types of financial institutions. Security has been found an important factor that motivates Saudi users to adopt online banking (Alhinai et al., 2013; Alhaliq \& AlMuhirat, 2016; Khalfan, 2006). The effect of attitude on intention has also been supported in the internet banking domain (Agarwal et al., 2009; Jaruwachirathanakul \& Fink, 2005; Kleijnen et al., 2004; Tan $\&$ Teo, 2000). These study results conclude that the attitude has played a significant role in influencing an individual's intention to adopt new technology.

Perceived risk is an essential element of consumers' internet banking decision-making process (Libermann \& Stashevsky, 2002). Lee (2009) defined perceived risk in internet banking as "the subjectively determined expectation of loss by an online bank user in contemplating a particular online transaction". Several studies discussed the influence of the perceived risk factor on individuals' attitude toward the adoption of the new technology services in general, and internet banking services, in particular (e.g. Tan \& Teo, 2000). According to Pavlou (2003), internet banking has fatal consumer privacy weaknesses; consumer concerns about security and privacy were reported by numerous researchers (Lee, 2009; Cunningham et al., 2005). Jahangir and Begum's (2008) study created a set of four items for measuring perceived web privacy. Its' result indicated that ease of use, privacy, security, perceived usefulness and consumer attitude toward use are positively and significantly related to customer adoption. Some online consumers are anxious about internet connection quality, and the possibility of poor connection quality poses a significant risk to banking transactions (Kuisma et al., 2007).

Rotchanakitumnuai and Speece (2003) found that trust and security are a significant risk that consumer perceives while using internet banking. Pikkarainen concluded that absence of security in the online environment 
constitutes significant threats to users as they fear that their privacy may be compromised and funds being lost (Pikkarainen et al., 2004; Yousafzai et al., 2010). Dimitriadis and Kyrezis (2010) have shown that familiarity with the internet has a positive influence on consumer trusting intention of internet banking. Numerous studies supported the significant positive effect of website information quality on users' trust in the internet and mobile banking services (Dimitriadis \& Kyrezis, 2010; Lin et al., 2011; Maroofi et al., 2013). Variables such as subjective norms, word-of-mouth referrals, perceived usefulness, perceived ease of use, enjoyment and relative benefits are relevant in influencing customers' initial trust toward an e-vendor (Aljaafreh, 2016; Grabner-Kraüter, 2011; Koufaris \& Hampton-Sosa, 2004; Lu \& Zhou, 2007; Suh \& Han, 2002). Johnson (2007) identified commitment and familiarity with technology as a relevant predictor of consumers' trust in online banking. Similarly, Grabner-Kräuter and Faullant $(2008,2009)$ found that familiarity with the internet significantly influences internet trust, which in turn impacts consumer attitude toward the use of internet banking. According to the Simon-Kucher Partners' (2015) survey, bank reputation is the second most important criterion considered by French consumers. Other studies have shown that bank reputation enhances consumers' initial trust in the internet and mobile banking (Dimitriadis \& Kyrezis, 2008; Kim, 2012; Montazemi \& Qahri-Saremi, 2015, Yousafzai et al., 2009). It has been shown that trust strongly affects the French consumers' decision to use internet banking and their loyalty toward it (Sahut et al., 2011; Sanchez \& Gallie, 2010). The perceived lack of control and personal contact in internet banking environment increases customers' concern for security and reliability of transactions (Flavián \& Guinalíu, 2006; Chiou \& Shen, 2012). These factors may reduce customer trust in internet banking (Lim, 2003), which might have an additional effect on its adoption and continuance.

Hernandez and Mazzon (2007) reviewed various adoption models and proposed an integrated theoretical model for internet banking adoption. The empirical results show that technology characteristics, perceived behavioural control, and individual characteristics determine the actual use of internet banking. In another study, Al-Somali et al. (2009) proposed that the quality of internet connection, awareness of service, trust, social influence, resistance to change, computer self-efficacy, and demographic characteristics along with technology determines usefulness and ease of internet banking and thus forms the basis of attitude and intentions toward internet banking. Lee et al. (2011) found that offline trust, offline loyalty and switching costs play a crucial role in customers' switching intentions to internet banking. Liébana-Cabanillas et al. (2013) found that accessibility, trust, ease of use and usefulness determine the customer satisfaction with internet banking.

Various studies reveal that the adoption rate of internet banking was low due to many factors: customers' perceptions of risk, their specific needs, lack of knowledge about internet banking, inertia, accessibility of technology, pricing, and IT fatigue (Gerrard et al., 2006). One of the main factors that consistently appear in the literature in different settings is the matter of security. Research showed privacy and security are the most influential factors in business (Hajli \& Lin, 2016) and indeed in internet banking acceptance in different countries (Laforet \& Li, 2005; Liao \& Cheung, 2002; Poon, 2008; Sadiq Sohail \& Shanmugham, 2003; Sayar \& Wolfe, 2007; Shah \& Siddiqui, 2006). Security issues are still important issues in internet banking, although the development of IT has empowered banks to better secure their platforms (White \& Nteli, 2004). For instance, banks in the UK provide card readers to reassure their customers and ensure that internet banking is secure. Some research showed that although customer satisfaction is fairly high in the UK, security and fraud are still the main concerns among consumers (Forsee, 2011). The speed of internet banking (Poon, 2008), customer satisfaction during the previous interaction with internet banking services (Casaló et al., 2008; Lymperopoulos \& Chaniotakis, 2004), and managers' perceptions (Lymperopoulos \& Chaniotakis, 2004; Shah \& Siddiqui, 2006) were the other important factors influencing the acceptance of internet banking. Additionally, trust and perceived usefulness are also important factors in the acceptance of internet banking (Liao \& Cheung, 2002; Suh \& Han, 2002). Another significant factor in internet banking adoption is the website and platform of the bank (Forsee, 2011). Davis et al. (1989) mentioned that users might decide to use a technology based on reasons other than one's own beliefs and feelings. Another important factor influencing internet banking adoption is banking consumers' awareness about internet banking (Sathye, 1999; Pikkarainen et al., 2004). Many studies establish the relationship between computer literacy and the degree of use of internet banking (Davis, 1989; Wang et al., 2003). Shah and Siddiqui's (2006) study of internet banking adoption revealed that critical success factors for the adoption of internet banking were: availability of resources, security, understanding customer needs, bank flexibility, bank brand name, integration of channels and systems, support from top management and customer service quality.

\section{Methodology}

\subsection{Research Objectives}

This research paper aims to analyse the factors that play an essential role in influencing the adoption of internet 
banking amongst Saudi Arabian banking consumers.

\subsection{Research Design}

To this objective, our study employs a quantitative approach which is descriptive research in nature. The study is investigation based on data collected through a questionnaire.

\subsection{Research Instrument}

To this end, a questionnaire consisting of 17 statements related to Internet Banking usage was prepared. The questionnaire collected responses from the banking consumers on five-point Likert Scale ranging from Strongly Disagree $=1$ to Strongly Agree $=5$. The research instrument was developed based on variables collected from the existing literature.

\subsection{Sample and its Characteristics}

Participation of respondents in this study was entirely voluntary. Respondents were asked to complete a survey questionnaire based on their opinions and beliefs towards the adoption and use of internet banking. Those participants were briefed on the objectives of the current study and told of their rights to withdraw before, during or after they had completed the questionnaire. Respondents were also ensured that their responses in survey questionnaire would be used only for fulfilling the objectives of the present research and not for any other purposes. 400 questionnaires were distributed out of which 300 completed questionnaires were collected from respondents and were used for analysis and further proceedings.

\subsection{Data Processing and Analysis}

After the collection of questionnaires, the data thus collected has been processed for analysis. For analysis purpose, we used statistical tools such as mean standard deviation. To find out the reliability of the research instrument, we applied Cronbach Alpha. Exploratory factor analysis (EFA) has been considered to extract essential factors from select 17 variables.

To understand the work done on internet banking, we present here some significant works conducted by scholars during the last decade is presented below in Table 1.

Table 1. Internet banking research to date

\begin{tabular}{|c|c|c|}
\hline Author (s) & Year & Factors Influencing Internet Banking Consumer Behavior \\
\hline Kiran J. Patel and Hiren J. Patel & 2018 & Internet banking \& security, usefulness, ease of use and social influence \\
\hline Souheila Kaabachi et al., 2017 & 2017 & Trust and internet banking adoption in France. \\
\hline Muslim Amin & 2016 & Internet banking service quality, customer satisfaction and loyalty \\
\hline Awni Rawashdeh & 2015 & Technology Acceptance Model (TAM) as the prediction \\
\hline Rambalak Yadav et al., & 2015 & Risk perception and adoption of internet banking \\
\hline $\begin{array}{l}\text { Pallab Sikdar, Amresh Kumar and } \\
\text { Munish Makkad }\end{array}$ & 2015 & Trust, usability, ease, accessibility and intention to adopt internet banking \\
\hline \multirow[t]{3}{*}{ Tina Suzanne Harrison et al., } & 2014 & Variables reflecting consumer experience \\
\hline & & $\begin{array}{ll}\text { 1. } & \text { Prior knowledge and experience of } \\
2 . & \text { Awareness } \\
3 . & \text { Technological access } \\
4 . & \text { Technological experience } \\
5 . & \text { Banking involvement } \\
6 . & \text { Risk awareness and perception } \\
7 . & \text { Readiness for change } \\
8 . & \text { Service delivery. }\end{array}$ \\
\hline & & Additionally, other channel-related predictor/variables \\
\hline Nabil Mzoughi and Wafa M'Sallem & 2013 & Behaviour prediction factors \\
\hline Ather Akhlaq and Ejaz Ahmed & 2013 & Motivation and internet banking \\
\hline $\begin{array}{l}\text { Shumaila Yousafzai and Mirella } \\
\text { Yani-de-Soriano }\end{array}$ & 2012 & Validation of customer-specific internet banking acceptance model (CSIBAM) \\
\hline $\begin{array}{l}\text { Ankit Kesharwani and Shailendra } \\
\text { Singh Bisht }\end{array}$ & 2012 & Risk perception banking consumers' intention to adopt internet banking \\
\hline Anita Life Zhao et al., & 2010 & Relationship trust and perceived risk \\
\hline Alain Yee-Loong Chong et al. & 2010 & Evidence from Vietnam \\
\hline
\end{tabular}




\section{Results}

\subsection{Reliability Test}

Table 2 demonstrates reliability position of the survey questionnaire used in the present study. It is evident in table 2 that for 17 items of the research instrument (survey questionnaire) Cronbach's Alpha value is .982 which point out very high reliability and internal consistency of the study instrument. In this condition, it can be concluded that the questionnaire and select variable of this research are very much appropriate to fulfil the research objectives.

Table 2. Reliability test (Cronbach's alpha)

\begin{tabular}{ll}
\hline Online Banking & $\mathbf{. 9 8 2}$ \\
Easy to use & $\mathbf{1 7}$ \\
Transactional Ease \\
Interactional Clarity \\
Learning Ease \\
Flexibility \\
Trust in Banking Technology \\
Consumer Privacy \\
Financial Security \\
Security of Online Banking \\
Transactional Effectiveness \\
Transactional Efficiency \\
Transactional Speed \\
Usefulness \\
Information \\
Information on Benefits \\
Pleasant Experience \\
Usage Positive
\end{tabular}

\subsection{Channels of Using Banking Services}

Results in Table 3 show that $69.3 \%$ of the respondents use internet banking and $61.3 \%$ use mobile banking.

Table 3. Channel of using banking services

\begin{tabular}{lcccc}
\hline Mode of Banking & Yes & No & Yes & No \\
\hline Use Internet Banking & 208 & 92 & $69.3 \%$ & $30.7 \%$ \\
Use Mobile Banking & 184 & 116 & $61.3 \%$ & $38.7 \%$ \\
\hline
\end{tabular}

\subsection{Factors Important in Internet Banking}

Tables 4 to 6 show the results of factors in online banking which may influence the decision of customers in selecting a bank. From the existing literature, we identified 17 factors in online banking. Table 4 presents the mean values whereas the results in Table 5 and Table 6 show the responses frequencies and percentage. The results in Table 7 make factor analysis to group the factors in various groups, i.e. Trust, Ease/Convenience, Efficiency/Effectiveness and Information.

Mean values for 14 factors were found 4 and above indicating their importance for the customers. Mean values higher than 4 in ascending order were [e.g., Trust the security of online banking (4.32), Trust in online bank technology (4.31), Trust that online bank will protect the privacy (4.30), Online bank improves performance of utilizing banking services (4.30), Trust that an online bank is financially secure (4.29), Online bank enables to utilize banking services more quickly (4.27), Online bank enhances the effectiveness of utilizing banking services (4.26), Easy to get the desired services (4.23), Clear and understandable interaction with an online bank (4.22), Easy to use online banking (4.18), Learning to use online banking is secure (4.17), Flexibility in using online banking (4.17), Using an online bank is positive (4.12), Overall online bank is useful (4.01)]. Three variables having a mean value less than 4 were [e.g., Information about benefits of using online bank (3.90), Using an online bank is pleasant (3.89), and Information about the online bank (3.88)]. 
Table 4. Descriptive statistics- “ONLINE BANKING” facilities influence the decision to select a bank

\begin{tabular}{llll}
\hline Factors & $\mathbf{N}$ & Mean & Std. Deviation \\
\hline Easy to use & 300 & 4.18 & 1.399 \\
Transactional Ease & 300 & 4.23 & 1.327 \\
Interactional Clarity & 300 & 4.22 & 1.346 \\
Learning Ease & 300 & 4.17 & 1.307 \\
Flexibility & 300 & 4.17 & 1.329 \\
Trust in Banking Technology & 300 & 4.31 & 1.232 \\
Consumer Privacy & 300 & 4.30 & 1.297 \\
Financial Security & 300 & 4.29 & 1.316 \\
Security of Online Banking & 300 & 4.32 & 1.294 \\
Transactional Effectiveness & 300 & 4.26 & 1.278 \\
Transactional Efficiency & 300 & 4.27 & 1.313 \\
Transactional Speed & 300 & 4.30 & 1.221 \\
Usefulness & 300 & 4.01 & 1.321 \\
Information & 300 & 3.88 & 1.316 \\
Information on Benefits & 300 & 3.90 & 1.332 \\
Pleasant Experience & 300 & 3.89 & 1.327 \\
Usage Positive & 300 & 4.12 & 1.339 \\
\hline
\end{tabular}

Table 5. "ONLINE BANKING" facilities influence the decision to select a bank

\begin{tabular}{|c|c|c|c|c|c|}
\hline \multirow[t]{2}{*}{ Factors } & \multicolumn{5}{|c|}{ Number of respondents reporting } \\
\hline & Strongly Disagree & Disagree & Somewhat agree & Agree & Strongly Agree \\
\hline Easy to use & 36 & 10 & 24 & 23 & 207 \\
\hline Transactional Ease & 27 & 19 & 18 & 31 & 205 \\
\hline Interactional Clarity & 28 & 19 & 20 & 25 & 208 \\
\hline Learning Ease & 21 & 27 & 27 & 29 & 196 \\
\hline Flexibility & 27 & 17 & 30 & 30 & 196 \\
\hline Trust in Banking Technology & 21 & 14 & 27 & 27 & 211 \\
\hline Consumer Privacy & 27 & 13 & 19 & 25 & 216 \\
\hline Financial Security & 29 & 12 & 18 & 24 & 217 \\
\hline Security of Online Banking & 27 & 12 & 20 & 21 & 220 \\
\hline Transactional Effectiveness & 22 & 19 & 26 & 24 & 209 \\
\hline Transactional Efficiency & 29 & 10 & 24 & 24 & 213 \\
\hline Transactional Speed & 22 & 10 & 29 & 33 & 206 \\
\hline Usefulness & 23 & 27 & 41 & 43 & 166 \\
\hline Information & 22 & 30 & 57 & 44 & 147 \\
\hline Information on Benefits & 24 & 28 & 53 & 43 & 152 \\
\hline Pleasant Experience & 23 & 26 & 65 & 32 & 154 \\
\hline Usage Positive & 27 & 20 & 30 & 35 & 188 \\
\hline
\end{tabular}

Table 6. "ONLINE BANKING" facilities influence the decision to select a bank

\begin{tabular}{lccccc}
\hline \multirow{2}{*}{ Factors } & \multicolumn{4}{c}{ Percent of respondents reporting } \\
\cline { 2 - 6 } & Strongly Disagree & Disagree & Somewhat agree & Agree & Strongly Agree \\
\hline Easy to use & 12.0 & 3.3 & 8.0 & 7.7 & 69.0 \\
Transactional Ease & 9.0 & 6.3 & 6.0 & 10.3 & 68.3 \\
Interactional Clarity & 9.3 & 6.3 & 6.7 & 8.3 & 69.3 \\
Learning Ease & 7.0 & 9.0 & 9.0 & 9.7 & 65.3 \\
Flexibility & 9.0 & 5.7 & 10.0 & 10.0 & 65.3 \\
Trust in Banking Technology & 7.0 & 4.7 & 9.0 & 9.0 & 70.3 \\
Consumer Privacy & 9.0 & 4.3 & 6.3 & 8.3 & 72.0 \\
Financial Security & 9.7 & 4.0 & 6.0 & 8.0 & 72.3 \\
Security of Online Banking & 9.0 & 4.0 & 6.7 & 7.0 & 73.3 \\
Transactional Effectiveness & 7.3 & 6.3 & 8.7 & 8.0 & 69.7 \\
Transactional Efficiency & 9.7 & 3.3 & 8.0 & 8.0 & 71.0 \\
Transactional Speed & 7.3 & 3.3 & 9.7 & 11.0 & 68.7 \\
Usefulness & 7.7 & 9.0 & 13.7 & 14.3 & 55.3 \\
Information & 7.3 & 10.0 & 19.0 & 14.7 & 49.0 \\
Information on Benefits & 8.0 & 9.3 & 17.7 & 14.3 & 50.7 \\
Pleasant Experience & 7.7 & 8.7 & 21.7 & 10.7 & 51.3 \\
Usage Positive & 9.0 & 6.7 & 10.0 & 11.7 & 62.7 \\
\hline
\end{tabular}




\subsection{Online Banking Factors: Exploratory Factor Analysis (EFA)}

To explore the factors from select 17 variables used in this study exploratory factor analysis (EFA) technique has been used. The results of a rotated component matrix in Table 7 show that out of seventeen (17) variables, fifteen variables were extracted by the factor analysis technique. Two Variables, i.e. online bank enables to utilize banking services more quickly and to use an online bank is pleasant were discarded from factor analysis due to low factor loading. After those four (4) different factors has been extracted from 15 variables (e.g., Trust consisting four variables, Ease/Convenience including five variables, efficiency and effectiveness with four variables, and information holding two variables). Trust factor shows that the customer will use online banking if they "trust that online bank will protect the privacy", "trust that online bank is financially secure", "trust the security of online banking", and "trust the online bank technology". The customers are looking for "learning to use online banking is easy", "easy to use online banking", and "clear and understandable interaction with an online bank", "flexibility of using online banking", and "easy to get the desired service". Efficiency and effectiveness of online banking include "online banking improve the performance of utilizing banking services", "online bank enables the effectiveness of utilizing banking services", "using an online bank is positive". The information factor comprises of "Information about online bank", and "Information about the benefits of using online bank". Table 7 shows that information loading of all two variables, i.e. information about the online bank (FL .862) and information about benefits of using online bank (FL .860) is highest among all the extracted variables. It means these two variables are significant for consumers in adopting internet banking services. Other variables with highest factor loading were [e.g., trust that online bank will protect the privacy (FL .763); trust that online bank is financially secure (FL .757) and trust upon the security of online banking (FL .754)]. It means after information; the trust is also a very significant variable among consumers to adopt internet banking of any banking institution. The analysis also shows that these fifteen variables are making a total of $91.508 \%$ variance in whole data which denotes their importance at a higher intensity in the present research.

Table 7. Rotated component matrix-“ONLINE BANKING” facilities influence decision to select a bank

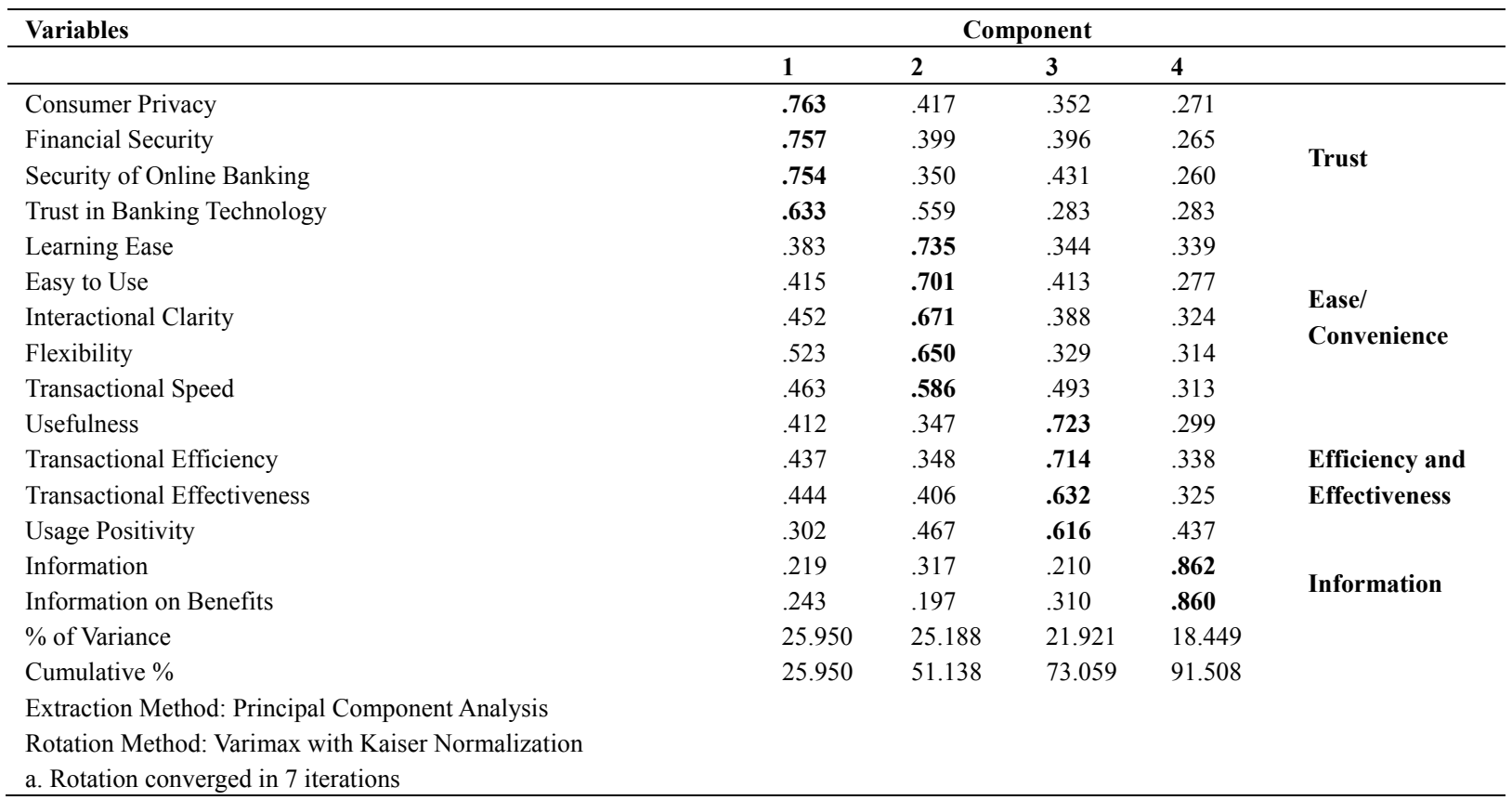

\section{Discussion}

The present study focuses on factors which are essential in the adoption of internet banking in Saudi Arabia. Study results showed that $69.3 \%$ of the consumers were using online banking.

\subsection{Importance of Select Variables}

In the current research, all select seventeen variables were found very important and significant for consumers in adopting internet banking. This is because the mean value of most of the variable (fourteen variables) was more than four (4) and rest three variables also have the mean value above 3.50. These high mean values indicate the 
significance of select seventeen variables in this study. We can explain the importance of these select variables can as the following.

\subsection{Security of Online Banking}

Security in the use of Internet banking is a very dominant issue for the consumers who use online banking to do their financial transactions. The maximum mean value for these variables confirms its importance in this study. This study result confirms the research findings of Alhinai et al., 2013, Alhaliq and AlMuhirat, 2016; Khalfan, 2006; Jahangir and Begum, 2008. Further the results conform to the findings of Lee, 2009; Cunningham et al., 2005; Rotchanakitumnuai and Speece, 2003; Pikkarainen et al., 2004; Yousafzai et al., 2010. These studies found that security is a big concern for internet banking users to make a transaction online. This may be because the banking being a financial issue renders people very cautious about their hard earned savings. Therefore, the security issue is a significant concern in internet banking use for the consumers.

\subsection{Trust in Online Bank Technology}

We prove that trust in internet banking technology is a critical factor for the consumers before they are ready to opt for internet banking. In current research holding the second highest mean value, this variable proves its significance in internet banking use. Importance of this variable is confirmed earlier by many researchers like Manochehri and Sundarraj, 2011, Rexha et al., 2003, Han, 2002, Rotchanakitumnuai and Speece, 2003, Dimitriadis and Kyrezis, 2010, Lin et al., 2011, Maroofi et al., 2013, Johnson, 2007, Grabner-Kräuter, 2008 and Faullant, 2009. Trust is the base of every transaction. The consumers will buy or use a product or service which they trust that that will be useful for them and this condition also applies to internet banking technology.

\subsection{Consumer Privacy}

In present research privacy protection in internet banking has been found a significant, significant variable in the adoption of internet banking with the mean value higher than four. This analysis result part is familiar to the previous study conclusions of Kwon and Wen, 2010; Jahangir and Begum, 2008; Hajli and Lin, 2016; Lee, 2009; Cunningham et al., 2005, in which they found that privacy issue is crucial in the adoption of internet banking. This issue is so important for consumers because financial matters are confidential matters and most of the people do not want to share any information towards the outsider without their consent. Here privacy includes many issues, i.e., password protection. Therefore, people will accept online banking when they will be sure that their financial matters related issues will be kept confidential while doing the transaction on the internet.

\subsection{Transactional Efficiency}

The issue that online banking improves the performance of utilizing banking services also holds a significant value with a high mean value above than four. It is evident that online banking is somewhat better than branch banking in some cases, i.e. people feel much convenient in a transaction from their PCs and mobiles anywhere apart from the bank branches. It saves peoples' time, money, and effort from going to bank branches for financial transactions. Therefore, it makes much efficient and improves the performance of bank services for the consumers.

\subsection{Financial Security}

Financial security is a significant concern in this study with a higher mean value. (4.29). The consumer will prefer that service in financial issues which they feel that that particular service is financially secure and there is very less chance of leakage of information about their bank accounts, passwords and other transactions. Hence in this study, this variable had gained a significant recognition to prove its importance in the adoption of internet banking among consumers.

\subsection{Transactional Speed}

In the present era consumers know the value of time, they also want banking services more time effective, and they put much emphasis on the time factor of any financial transaction. In this study utilization of banking services more quickly through online banking has got importance through high mean value. It means quick service in a banking transaction is a significant issue, and previous researches of Ayo et al. also confirm it., 2016; Hui Ling et al., 2015; Lee, 2009; Tan \& Teo, 2000; Yousafzai et al., 2003 that transaction speed makes a significant role in the adoption of internet banking.

\subsection{Transactional Effectiveness}

Nowadays banks provide various types of services to their consumers. With the help of internet banking utilization of these services could be enhanced effectively. In the present study, this issue has gained a significant mean value of (4.26). This may be because consumers can utilize banking services on their own without 
consuming extra time, money or effort. Many banks educate their consumers to utilize banking services moiré effectively through internet banking, and consumers are also making them aware of these issues which show its importance for consumers in the adoption of internet baking.

\subsection{Transactional Ease}

In present cutthroat competitive business environment banking institutions are conducting more research to know the need of their consumers. In this study variable named "easy to get the desired services" has got a significantly higher mean value which shows its importance in the adoption of internet banking. This may be because there are a variety of services provided by banks for the consumers, and when a consumer is using internet banking he or she can adopt a better banking service for making a financial transaction, and when consumer finds that it is easy to get their desired services they are motivated to adopt internet banking.

\subsection{Interactional Clarity}

The issue of clear and understandable interaction with an online bank has also been found a significant variable in the present study with a higher mean value. It is evident that when there is clarity and right environment with online banking service after that consumer can utilize that particular internet bank service if the consumer does not understand the online banking transaction, it will be difficult for consumers to adopt online banking transaction.

\subsection{Easy to Use}

Easy to use online banking is also a significant variable which been extracted from the current study. Nowadays many people use the internet, and they are much familiar with internet protocols. In current years people are much aware how to use internet banking through the internet on personal computers or smart phones. Due to much use of internet people can prefer internet banking rather than Branch banking.

\subsection{Learning Ease}

Learning the online banking is also an important issue nowadays among the consumers. In the present study, this issue has got a significant mean value. Nowadays many consumers use smart phones laptops and PCs for internet purpose. They use internet with very familiarity. In the view of consumers learning internet banking is easy because the maximum process of online banking is familiar to them and this is a technical process, so they have to learn it. Therefore, the consumer will attract towards internet banking when they are conveyed that learning internet baking is easy.

\subsection{Flexibility}

The flexibility in using online banking is also a very significant variable in adopting online banking from the consumer side. Here flexibility means Consumers convenience and pleasure towards internet banking at their own flexible time and desires. This variable also has a significant position the present research because consumers always want to be flexible nowadays so that they can do all financial transaction in the manner that they could do it very conveniently.

\subsection{Usage Positivity}

This variable has also gained a significant position in research. Using online banking is positive for consumers because consumers feel that there is no any adverse effect from doing online banking. This mentality of consumers will attract them towards internet banking because most of the consumers will feel that there is no harm and the adverse effect of making a transaction online.

\subsection{Usefulness}

Variable overall online banking is useful also have a significant higher meanwhile in analysis results. Consumer who uses internet banking feels that using internet baking is useful in many ways like it saves money, effort and time, financial transaction in internet banking could be done without visiting the bank branches, it could be done anytime and anywhere and some other benefits tend to consumer mentality that using internet banking is overall useful.

\subsection{Information on Benefits}

This variable also has been found to have significant high mean value. Nowadays information in business environment plays a significant role in the success of any business. In the case of internet baking, it is vital to inform the consumers about the benefits of using internet banking. When consumers are well informed about the benefits of internet banking, they will be motivated to adopt it. 


\subsection{Pleasant Experience}

Using an online bank is pleasant is also a significant variable in the adoption of online banking because the results here show a significant mean value for it. A person only wants to do work with joy and convenience when he feels pleasant about this work. By doing the financial transaction through the internet, the consumer should feel the pleasant environment and not dull or unpleasant. If he feels pleasant, the enthusiasm and mode of the transaction will be excellent and much convenience for consumers.

\subsection{Information}

Information about the online bank is also necessary for consumers because the consumer will do online baking when they are correctly informed about the modes and techniques of doing the transaction online. This variable also holds a good mean value in this research. In an online environment especially for financial transaction matters information about every single process of doing online traction is so essential for consumers to do this type of deals.

\subsection{Extracted factors from Exploratory Factor Analysis (EFA)}

From factor Analysis procedure four factors had been extracted from 15 variables which have been captioned trust, ease/convenience, Efficiency and effectiveness and Information by the researcher.

\subsection{Information}

Within total 15 factors "Information" with two variables has the maximum factor loading which shows its importance in internet banking adoption. This is because to adopt any product or service proper information about its use, advantages and disadvantages are must for any consumer.

\subsection{Trust}

The second extracted factor has been captioned "Trust" with four variables which holds factor loading above than .70. In trust factor, all the variables are making a significant presence in the analysis which shows their importance in this research. Trust is a significant factor in the minds of consumers when they want to adopt internet banking, and various studies confirm this, i.e. Rexha et al., 2003; Rotchanakitumnuai and Speece, 2003; Dimitriadis and Kyrezis, 2010; Lin et al., 2011; Maroofi et al., 2013.

\subsection{Ease/ Convenience}

The third factor which is extracted from EFA is "Ease/ Convenience" in online banking consisting of five variables. In this factor two variables are holding factor loading more than .70, two variables more than .650 and one variable more than .550 which shows their significance for the study. In previous researches TAM model introduced by Davis et al., (1989) which is considered a landmark model in the adoption of internet banking among the consumers also focuses on "Ease/ Convenience" of the technology to adopt it by the people. Importance of this factor has also been proved by the research findings of Cheng et al., 2006; Fawzy and Esawai, 2017; Kwon and Wen, 2010; and Al-Somali et al., 2009.

\subsection{Efficiency and Effectiveness}

The fourth and last extracted factor is "Efficiency and Effectiveness" of online banking in the view of consumers. This factor holds a total of four variables in which two variables hold factor loading more than .70 and two variables are with factor loading more than .60 which indicated their importance. A consumer will adopt any product or service which he will find that using that particular technology their efficiency is increasing. Therefore, efficiency or effectiveness of internet banking becomes a significant factor in adopting it which is also proved by the previous researches of Arnaboldi and Clayes, 2010; Celik, 2008; Koenig-Lewis et al., 2010 and Ozdemir et al., 2008.

\section{Conclusions and Implications}

Present study's main focus was to analyse the important factors in the adoption of internet banking in Saudi Arabian Banking consumers. Study results show that all seventeen variables taken into this study were found much relevant for consumers while they want to adopt and use internet banking. In the present research trust and security of online banking was found two be the most significant among the seventeen variables, on the other hand, other select variables were also found to be most significant for a consumer to adopt online banking. Exploratory Factor Analysis (EFA) technique has been used to find out the factors from select 17 variables used in this study.

Out of the seventeen (17) variables, fifteen variables were extracted by Factor Analysis. Two variable named online bank enables to utilise banking services more quickly and Using an online bank is pleasant were discarded from by Factor Analysis due to low Factor Loading. After those Four (4) different factors has been extracted. 
From the remaining fifteen variables, four variables named trust consisting four variables, Ease/Convenience including five variables, Efficiency and Effectiveness with four variables, and Information with two variables were extracted.

Within all four factors "Information," factor holds maximum factor loading variables which shows its importance in this research. In the present business, environment information has got a significant role in business organisations like banks. This is the task of management that they should adequately inform the consumers about internet banking, their benefits and convenience to the consumers so that they can adapt it easily. Information to the consumers could be given from various sources like the advertisement, personal intimation and other applicable sources.

Banks should make a robust internet security service to convey their consumers that their security protocols are much safer and almost impossible to crack it. Banking institutions can enhance the security of consumers accounts and their online transactions with the help of two-layer password protection [by One Time Password (OTP) system on registered mobile Number], by changing of security passwords time to time. By intimating the consumers when anytime the online account is accessed or any transaction has been made, by connecting the bank accounts details with registered email Id or any other measures should be adopted so that no third person could find even problematic access to the accounts or transaction information of any consumer. Through these measures trust in internet banking can be made in the minds of consumers and they can be motivated to adopt it.

The third-factor Ease/convenience is also necessary because nowadays people time is limited and they only adopt the things which are much convenient to them. In this case banking companies can make their internet banking much easy or convenience to the consumers by simplifying the online banking process. They should put lesser steps to access the accounts, should make easy tutorials to do internet transactions. They should provide various financial services, e.g., challan generation, payment of bills, payment of taxes, mobile recharge, electricity and other payments should be made very easy and much convenience to the consumer so that they can be motivated to use internet banking.

About fourth factor efficiency and effectiveness, this is also important in the adoption of online banking. Banking institutions should focus on this issue by increasing by providing much more improved services which consumer can enjoy by visiting the bank branches like loan services. Banks should also speed up their web services, and they should make the structure of their websites much effective and interactive so that efficiency could be increased. By securing the passwords and transaction information and also time to time intimation to consumers about the online banking policies, security and privacy policies banks could propagate and advertise the effectiveness of their online transaction.

\subsection{Future Research Attempts}

Present research mainly focuses on analyzing the crucial factors in the adoption of internet banking in Saudi Arabia. This study uses 300 respondents for the survey. In future respondent's number could be increased. Similar research could also be carried out apart from Saudi Arabia in other developing countries. This study limits only to explore the critical factors. Extended research consisting correlational study could also be done to find out the relationship between significant adoption factors of internet baking. Effect of demographic characteristics on different factors of internet banking adoption could also be analyzed in further researches. Some other unexplored variables could also be included in future research to enhance the quality of results.

\section{References}

Agarwal, R., Rastogi, S., \& Mehrotra, A. (2009). Customers' perspectives regarding e-banking in an emerging economy. Journal of Retailing and Consumer Services, 16(5), 340-351. https://doi.org/10.1016/j.jretconser.2009.03.002

Akhlaq, A., \& Ahmed, E. (2013). The effect of motivation on trust in the acceptance of internet banking in a low-income country. International Journal of Bank Marketing, 31(2), 115-125. https://doi.org/10.1108/02652321311298690

Akinci, S., Aksoy, S., \& Atilgan, E. (2004). Adoption of internet banking among sophisticated consumer segments in an advanced developing country. International Journal of Bank Marketing, 22(3), 212-232. https://doi.org/10.1108/02652320410530322

Al-Ajam, A. S., \& Nor, K. M. (2015). Challenges of adoption of internet banking service in Yemen. International Journal of Bank Marketing, 33(2), 178-194. https://doi.org/10.1108/IJBM-01-2013-0001

Alhaliq, H. A., \& AlMuhirat, A. A. (2016). Customer satisfaction with electronic banking services in the Saudi 
banking sector. Asian Social Sciences, 12, 139-146. https://doi.org/10.5539/ass.v12n5p139

Alhinai, Y. S., Albadi, A., Alshihi, H., \& Algharbi, K. (2013). Investigating determinants of e-banking adoption by individuals: Comparing the impact of system characteristics and users traits. International Review of Management and Business Research, 2, 371.

Aljaafreh, A. O. (2016). An investigation of factors affecting initial trust in internet banking services in Jordan. Retrieved from https://opus.lib.uts.edu.au/bitstream/10453/44179/2/02whole.pdf

Al-Somali, S. A., Gholami, R., \& Clegg, B. (2009). An investigation into the acceptance of online banking in Saudi Arabia. Technovation, 29(2), 130-141. https://doi.org/10.1016/j.technovation.2008.07.004

Amin, M. (2016). Internet banking service quality and its implication on e-customer satisfaction and e-customer loyalty. International Journal of Bank Marketing, 34(3), 280-306. https://doi.org/10.1108/IJBM-10-2014-0139

Angelakopoulos, G., \& Mihiotis, A. (2011). E-banking: challenges and opportunities in the Greek banking sector. Electronic Commerce Research, 11(3), 297-319. https://doi.org/10.1007/s10660-011-9076-2

Arnaboldi, F., \& Clayes, P. (2010). Innovation and performance of European banks adopting internet. Working paper, Centre for Banking Research, Cass Business School, City University London, London.

Arunachalam, L., \& Sivasubramanian, M. (2007). The future of Internet banking in India. Academic Internet Open Journal, 20.

Ayo, C. K., Oni, A. A., Adewoye, O. J., \& Eweoya, I. O. (2016). E-banking users' behaviour: e-service quality, attitude, and customer satisfaction. International Journal of Bank Marketing, 34(3), 347-367. https://doi.org/10.1108/IJBM-12-2014-0175

Ba, S. (2001). Establishing online trust through a community responsibility system. Decision Support Systems, 31(3), 323-336. https://doi.org/10.1016/S0167-9236(00)00144-5

Booz, Allen, \& Hamilton. (1997). Internet Banking: A Global Study of Potential. New York, NY: Booz, Allen \& Hamilton Inc.

Casalo, L. V., Flavián, C., \& Guinalíu, M. (2007). The role of security, privacy, usability and reputation in the development of online banking. Online Information Review, 31(5), 583-603. https://doi.org/10.1108/14684520710832315

Casaló, L. V., Flavián, C., \& Guinalíu, M. (2008). The role of satisfaction and website usability in developing customer loyalty and positive word-of-mouth in the e-banking services. International Journal of Bank Marketing, 26(6), 399-417. https://doi.org/10.1108/02652320810902433

Chechen, L., Yi-Jen, H., \& Tung Heng, H. (2016). Factors Influencing Internet banking adoption. Social Behaviour and Personality: An International Journal, 44(9), 1443-1455. https://doi.org/10.2224/sbp.2016.44.9.1443

Chiou, J., \& Shen, C. (2012). The antecedents of online financial service adoption: the impact of physical banking services on internet banking acceptance. Behaviour \& Information Technology, 31(9), 859-871. https://doi.org/10.1080/0144929X.2010.549509

Chong, A. Y.-L., Ooi, K.-B., Lin, B., \& Tan, B.-I. (2010). Online banking adoption: an empirical analysis. International Journal of Bank Marketing, 28(4), 267-287. https://doi.org/10.1108/02652321011054963

Cunningham, L. F., Gerlach, J. M., \& Harper, D. (2005). Perceived risk and E-banking services: an analysis from the perspective of the consumer. Journal of Financial services marketing, 10(2), 165-178. https://doi.org/10.1057/palgrave.fsm.4770183

Daniel, E. (1999). Provision of electronic banking in the UK and the Republic of Ireland. International Journal of Bank Marketing, 17(2), 72-82. https://doi.org/10.1108/02652329910258934

Davis F. D., Bagozzi, R. P., \& Warshaw, P. R. (1989). User acceptance of computer technology: A comparison of two theoretical models. Management Sciences, 35(8), 982-1002. https://doi.org/10.1287/mnsc.35.8.982

Davis, F. D. (1989). Perceived usefulness, Perceived ease of use, and User acceptance of Information technology. MIS Quarterly, 13(3), 319-339. https://doi.org/10.2307/249008

Dimitriadis, S., \& Kyrezis, N. (2008). Does trust in the bank build trust in its technology-based channels? Journal of Financial Services Marketing, 13(1), 28-38. https://doi.org/10.1057/fsm.2008.3 
Dimitriadis, S., \& Kyrezis, N. (2010). Linking trust to use intention for technology-enabled bank channels: the role of trusting intentions. Psychology and Marketing, 27(8), 799-820. https://doi.org/10.1002/mar.20358

Fawzy, S. F., \& Esawai, N. (2017). Internet banking adoption in Egypt: Extending the technology acceptance model. Journal of Business and Retail Management Research, 12(1), 109-118. https://doi.org/10.24052/JBRMR/V12IS01/IBAIEETAM

Forsee. (2011). ForeSee results launch first UK customer satisfaction report for online banking. Retrieved from www.foresee.com

Furst, K., Lang, W. W., \& Noelle, D. E. (2002). Internet banking. Journal of Financial Services Research, 22(1/2), 95-117. https://doi.org/10.1023/A:1016012703620

Gan, C., Clemes, M., Limsombunchai, V., \& Weng, A. (2006). A logit analysis of electronic banking in New Zealand. International Journal of Bank Marketing, 24(6), 360-383. https://doi.org/10.1108/02652320610701717

George, A., \& Kumar, G. S. (2013). Antecedents of customer satisfaction in internet banking: Technology Acceptance Model (TAM) redefined. Global Business Review, 14(4), 627-638. https://doi.org/10.1177/0972150913501602

Gerrard, P., Cunningham, J. B., \& Devlin, J. F. (2006). Why consumers are not using internet banking: a qualitative study. Journal of Services Marketing, 20(3), 160-168. https://doi.org/10.1108/08876040610665616

Grabner-Kraüter, S. (2011). Factors influencing online banking adoption: evidence from the Austrian market. International Journal of Internet Marketing and Advertising, 6(4), 331-351.

Grabner-Kräuter, S., \& Faullant, R. (2008). Consumer acceptance of internet banking: the influence of internet

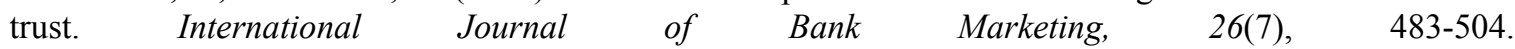
https://doi.org/10.1108/02652320810913855

Grabner-Kräuter, S., \& Faullant, R. (2009). The impact of internet trust on the adoption of internet banking and the moderating role of personality. American Marketing Association, Winter Educators' Conference, pp. 123-133.

Hajli, N., \& Lin, X. (2016). Exploring the security of information sharing on social networking sites: the role of perceived control of information. Journal of Business Ethics, 133(1), 111-123. https://doi.org/10.1007/s10551-014-2346-x

Harrison, T. S., Onyia, O. P., \& Tagg, S. K. (2014). Towards a universal model of internet banking adoption: initial conceptualization. International Journal of Bank Marketing, 32(7), 647-687. https://doi.org/10.1108/IJBM-06-2013-0056

Hernandez, J. M. C., \& Mazzon, J. A. (2007). Adoption of internet banking: proposition and implementation of an integrated methodology approach. International Journal of Bank Marketing, 25(2), 72-88. https://doi.org/10.1108/02652320710728410

Hui Ling, C., Islam, M. A., Abdul Manaf, A. H., \& Wan Mustafa, W. M. (2015). Users satisfaction towards online banking in Malaysia. International Business Management, 9(1), 15-27.

Jahangir, N., \& Begum, N. (2008). The role of perceived usefulness, perceived ease of use, security and privacy, and customer attitude to engender customer adaptation in the context of electronic banking. African Journal of Business Management, 2(1), 32-40.

Jaruwachirathanakul, B., \& Fink, D. (2005). Internet banking adoption strategies for a developing country: the case of Thailand. Internet Research, 15(3), 295-311. https://doi.org/10.1108/10662240510602708

Johnson, D. S. (2007). Achieving customer value from electronic channels through identity commitment, calculative commitment, and trust in technology. Journal of Interactive Marketing, 21(4), 2-22. https://doi.org/10.1002/dir.20091

Jourdan, J., \& Katz, J. (1999). Banking in the age of information technology. Regional Review, 9(2), 24-30.

Kaabachi, S., Mrad, S. B., \& Petrescu, M. (2017). Consumer initial trust toward internet-only banks in France. International Journal of Bank Marketing, 35(6), 903-924. https://doi.org/10.1108/IJBM-09-2016-0140

Kesharwani, A., \& Bisht, S. S. (2012). The impact of trust and perceived risk on internet banking adoption in India: An extension of technology acceptance model. International Journal of Bank Marketing, 30(4), 
303-322. https://doi.org/10.1108/02652321211236923

Keswani, S., \& Chaturvedi, M. (2010). Impact of customer's awareness on their satisfaction: a study on e-banking in Gwalior City. SIES Journal of Management, 6(2), 81-93.

Khaflan, A. M. S., AlRefaei, Y. S., \& AlHajery, M. (2006). Factors influencing the adoption of internet banking in Oman: A descriptive case study analysis. International Journal of Financial Services Management, 1, 155-172. https://doi.org/10.1504/IJFSM.2006.009623

Kim, J. B. (2012). An empirical study on consumer first purchase intention in online shopping: integrating initial trust and TAM. Electronic Commerce Research, 12(2), 125-150. https://doi.org/10.1007/s10660-012-9089-5

Kleijnen, M., Wetzels, M., \& Ruyter, K. (2004). Consumer acceptance of wireless finance. Journal of Financial Services Marketing, 8(3), 206-217. https://doi.org/10.1057/palgrave.fsm.4770120

Koufaris, M., \& Hampton-Sosa, W. (2004). The development of initial trust in an online company by new customers. Information \& Management, 41(3), 377-397. https://doi.org/10.1016/j.im.2003.08.004

Kuisma, T., Laukkanen, T., \& Hiltunen, M. (2007). Mapping the reasons for resistance to internet banking: a means-end approach. International Journal of Information Management, 27, 75-85. https://doi.org/10.1016/j.ijinfomgt.2006.08.006

Kwon, O., \& Wen, Y. (2009). An empirical study of the factors affecting social network service use. Computers in Human Behavior, 26, 254-263. https://doi.org/10.1016/j.chb.2009.04.011

Laforet, S., \& Li, X. (2005). Consumers' attitudes towards online and mobile banking in China. International Journal of Bank Marketing, 23(5), 362-380. https://doi.org/10.1108/02652320510629250

Lal, R., \& Savary M. (1999). When and How is the Internet likely to decrease price?. Marketing Science, 18, 485-503. https://doi.org/10.1287/mksc. 18.4 .485

Lee, M. C. (2009). Factors influencing the adoption of internet banking: an integration of TAM and TPB with perceived risk and perceived benefit. Electronic Commerce Research and Applications, 8(3), 130-141. https://doi.org/10.1016/j.elerap.2008.11.006

Liao, Z., \& Cheung, M. T. (2002). Internet-based e-banking and consumer attitudes: an empirical study. Information \& Management, 39(4), 283-295. https://doi.org/10.1016/S0378-7206(01)00097-0

Libermann, Y., \& Stashevsky, S. (2002). Perceived risks as a barrier to internet and e-commerce usage. Qualitative Market Research, 5(4), 291. https://doi.org/10.1108/13522750210443245

Liébana-Cabanillas, F., Muñoz-Leiva, F., \& Rejón-Guardia, F. (2013). The determinants of satisfaction with e-banking". Industrial Management \& Data Systems, 113(5), 750-767. https://doi.org/10.1108/02635571311324188

Lim, N. (2003). Consumers' perceived risk: sources versus consequences. Electronic Commerce Research and Applications, 2(3), 216-228. https://doi.org/10.1016/S1567-4223(03)00025-5

Lin, J., Lu, Y., Wang, B., \& Kee Wei, K. (2011). The role of inter-channel trust transfer in establishing mobile commerce trust. Electronic Commerce Research and Applications, 10(4), 615-625. https://doi.org/10.1016/j.elerap.2011.07.008

Littler, D., \& Melanthiou, D. (2006). Consumer perceptions of risk and uncertainty and the implications for behaviour towards innovative retail services: the case of internet banking. Journal of Retailing and Consumer Services, 13(6), 431-443. https://doi.org/10.1016/j.jretconser.2006.02.006

Lu, Y., \& Zhou, T. (2007). A research of consumers' initial trust in online stores in China. Journal of Research and Practice in Information Technology, 39(2), 21-34.

Lymperopoulos, C., \& Chaniotakis, L. E. (2004). Branch employees' perceptions towards implications of e-banking in Greece. International Journal of Retail \& Distribution Management, 32(6), 302-311. https://doi.org/10.1108/09590550410538006

Markillie, P. (2004). A perfect market: A survey of e-commerce. The Economist. May $15^{\text {th }}$ to $21^{\text {st }}$.

Maroofi, F., Kahrarian, F., \& Dehghani, M. (2013). An investigation of initial trust in mobile banking. International Journal of Academic Research in Business and Social Sciences, 3(9), 394-402. https://doi.org/10.6007/IJARBSS/v3-i9/228

Montazemi, A. R., \& Qahri-Saremi, H. (2015). Factors affecting adoption of online banking: a meta-analytic 
structural equation modelling study. Information \& Management, 52(2), 210-226. https://doi.org/10.1016/j.im.2014.11.002

Mzoughi, N., \& M'Sallem, W. (2013). Predictors of internet banking adoption: Profiling Tunisian postponers, opponents and rejectors. International Journal of Bank Marketing, 31(5), 388-408. https://doi.org/10.1108/IJBM-10-2012-0105

Narayanasamy, K., Rasiah, D., \& Tan, T. M. (2011). The adoption and concerns of e-finance in Malaysia. Electronic Commerce Research, 11(4), 383-400. https://doi.org/10.1007/s10660-011-9081-5

Pavlou, P. A. (2003). Consumer acceptance of electronic commerce: Integrating trust and risk with the technology acceptance model. International Journal of Electronic Commerce, 7(3), 101-134. https://doi.org/10.1080/10864415.2003.11044275

Pikkarainen, T., Pikkarainen, K., Karjaluoto, H., \& Pahnila, S. (2004). Consumer acceptance of online banking: an extension of the technology acceptance model. Internet Research, 14(3), 224-235. https://doi.org/10.1108/10662240410542652

Polatoglu, V. N., \& Ekin, S. (2001). An empirical investigation of the Turkish consumers' acceptance of internet banking services. International Journal of Bank Marketing, 19(4), 156-165. https://doi.org/10.1108/02652320110392527

Poon, W.-C. (2008). Users' adoption of e-banking services: the Malaysian perspective. Journal of Business \& Industrial Marketing, 23(1), 59-69. https://doi.org/10.1108/08858620810841498

Qureshi, T. M., Zafar, M. K., \& Khan M. B. (2008). Customer Acceptance of online banking in developing economies. Journal of Internet Banking and Commerce, 13(1), 2-9.

Ramsey, J., \& Smith, M. (1999). Managing customer channel usage in the Australian banking sector. Managerial Auditing Journal, 14(7), 329-338. https://doi.org/10.1108/02686909910289812

Rawashdeh, A. (2015). Factors affecting adoption of internet banking in Jordan: Chartered accountant's

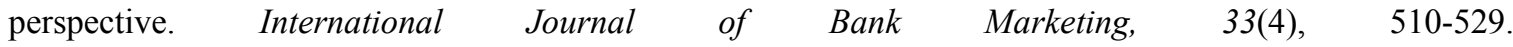
https://doi.org/10.1108/IJBM-03-2014-0043

Rexha, N., Jonh, R. P., \& Shang, A. S. (2003). The impact of the relational plan on adoption of electronic banking. Journal of Services Marketing, 17(1), 53-67. https://doi.org/10.1108/08876040310461273

Riffai, M. M., Grant, K., \& Edgar, D. (2012). Big TAM in Oman: exploring the promise of online banking, its adoption by customers and the challenges of banking in Oman. International Journal of Information Management, 32(3), 239-250. https://doi.org/10.1016/j.ijinfomgt.2011.11.007

Rotchanakitumnuai, S., \& Speece, M. (2003). Barriers to internet banking adoption: a qualitative study among corporate customers in Thailand. International Journal of Bank Marketing, 21(6/7), 312-323. https://doi.org/10.1108/02652320310498465

Sadiq S. M., \& Shanmugham, B. (2003). E-banking and customer preferences in Malaysia: an empirical investigation. Information Sciences, 150(3-4), 207-217. https://doi.org/10.1016/S0020-0255(02)00378-X

Sahut, J. M., Khalfallah, M., \& Mutte, J. L. (2011). Satisfaction et fidélisation aux services d'internet banking, quelle influence sur la fidélité à la banque?. Management \& Avenir, 7(47), 260-280. https://doi.org/10.3917/mav.047.0260

Sanchez, C. R., \& Gallie, J. B. (2010). Adoption of internet banking: evidence from France. International Journal of Management and Marketing Research, 3(3), 297-323.

Sathye, M. (1999). Adoption of the Internet banking by Australian consumers: an empirical investigation. International Journal of Bank Marketing, 17(7), 324-334. https://doi.org/10.1108/02652329910305689

Sayar, C., \& Wolfe, S. (2007). Internet banking market performance: Turkey versus the UK. International Journal of Bank Marketing, 25(3), 122-141. https://doi.org/10.1108/02652320710739841

Shah, M. H., \& Siddiqui, F. A. (2006). Organisational, critical success factors in the adoption of e-banking at the Woolwich bank. International Journal of Information Management, 26(6), 442-456. https://doi.org/10.1016/j.ijinfomgt.2006.08.003

Shih, Y. Y., \& Fang, K. (2004). The use of a decomposed theory of planned behaviour to study internet banking in Taiwan. Internet Research, 14(3), 213-223. https://doi.org/10.1108/10662240410542643

Simon-Kucher and Partners. (2015). Les banques traditionnelles face à l'évolution des banques en ligne...et 
demain des banques sur réseau social? Décembre, Paris. Retrieved from www.lesechos.fr/16/02/2016/LesEchos/22130-135-ECH_les-banques-en-ligne-gagnent-la-confiance-des-fra ncais.htm

Suh, B., \& Han, I. (2002). Effect of trust on customer acceptance of internet banking. Electronic Commerce Research and Applications, 1(3-4), 247-263. https://doi.org/10.1016/S1567-4223(02)00017-0

Tan, M., \& Teo, T. S. H. (2000). Factors influencing the adoption of internet banking. Journal of the Association for Information Systems, 1(1), 1-42. https://doi.org/10.17705/1jais.00005

Wang, Y. S., Wang, Y. M., Lin, H. H., \& Tang, I. (2003). Determinants of user acceptance of internet banking: an empirical study. International Journal of Service Industry Management, 14(5), 501-519. https://doi.org/10.1108/09564230310500192

White, H., \& Nteli, F. (2004). Internet banking in the UK: why are there not more customers? Journal of Financial Services Marketing, 9(1), 49-56. https://doi.org/10.1057/palgrave.fsm.4770140

Yadav, R., Chauhan, V., \& Pathak, G. S. (2015). Intention to adopt internet banking in an emerging economy: a perspective of Indian youth. International Journal of Bank Marketing, 33(4), 530-544. https://doi.org/10.1108/IJBM-06-2014-0075

Yang, J., Cheng, L., \& Luo, X. (2009). A comparative study on e-banking services between China and USA. International Journal of Electronic Finance, 3(3), 235-252. https://doi.org/10.1504/IJEF.2009.027848

Yousafzai, S. Y., Pallister, J. G., \& Foxall, G. R. (2003). A proposed model of e-trust for electronic banking. Technovation, 23(11), 847-860. https://doi.org/10.1016/S0166-4972(03)00130-5

Yousafzai, S., \& Yani-de-Soriano, M. (2012). 'Understanding customer-specific factors underpinning internet banking adoption. International Journal of Bank Marketing, 30(1), 60-81. https://doi.org/10.1108/02652321211195703

Yousafzai, S., Pallister, J., \& Foxall, G. (2009). Multi-dimensional role of trust in internet banking adoption. The Service Industries Journal, 29(4), 591-605. https://doi.org/10.1080/02642060902719958

Zettlemeyer, F., Morton, F. S., \& Risso, J. S. (2006). How the internet lowers prices: evidence from matched survey and automobile transaction data? Journal of Marketing Research, 43, 168-181. https://doi.org/10.1509/jmkr.43.2.168

Zhao, A. L., Koenig-Lewis, N., Hanmer-Lloyd, S., \& Ward, P. (2010). Adoption of internet banking services in China: is it all about trust? International Journal of Bank Marketing, 28(1), 7-26. https://doi.org/10.1108/02652321011013562

\section{Copyrights}

Copyright for this article is retained by the author(s), with first publication rights granted to the journal.

This is an open-access article distributed under the terms and conditions of the Creative Commons Attribution license (http://creativecommons.org/licenses/by/4.0/). 